\title{
Khakassia Symphony Orchestra in the Context of Musical Culture Development in the Republic
}

\author{
Emil M. Preisman ${ }^{\mathrm{a}}$ \\ and Marija I. Razdolieva ${ }^{\text {** }}$ \\ ${ }^{a}$ Krasnoyarsk State Art Institute \\ 22 Lenin Str., Krasnoyarsk, 660049, Russia \\ ${ }^{b}$ Children's Music School No. 12 \\ 11 Slovtsova Str., Krasnoyarsk, 660130, Russia
}

Received 15.01.2017, received in revised form 03.07.2017, accepted 12.07.2017

The article describes Khakassia symphony orchestra as a phenomenon caused by the republic industrial development that has stimulated the rise of the artistic culture. It regards economic and social background, organizational mechanisms of the orchestra staff formation. The analysis of creative documents (brochures, posters, newspaper articles) and decisions of administrative authorities, interviews with the orchestra veterans and some of its audience, comparison of the orchestra performances in different periods have revealed the ways of the orchestra development, its creative members, instrumental structure, characteristics of the repertoire, peculiar features of the performances, and the perspectives of further development. The orchestra is an organic element of the artistic culture of Khakassia, a factor of intensification of musical life in Abakan, a means of education of the population of the south of the Krasnoyarsk Krai, a creative laboratory piloting the Khakass composers' works. The orchestra activity is supported by the republic authorities, this being the key to broadening its creative prospects.

Keywords: Khakassia, artistic culture, musical life, the Khakass Republican Philharmonic named after V.G. Chaptykov, the Abakan music college, symphony orchestra, V.G. Inkizhekov, symphony, instrumental concert, cinema music, international cultural relations.

DOI: 10.17516/1997-1370-0113.

Research area: theory and history of art.

\section{Introduction}

At the turn of the XX-XXI centuries the artistic and, in particular, musical life of the Russian regions underwent visible intensification. It became evident that a full understanding of culture of the whole country, its past and present, and forecasting of culture development make it essential to study artistic creativity not only in the capitals about which volumes of art literature are written, but also in the regions with their distinctive character and many-sided nature. This caused the statement of the problem of a comprehensive study of regional cultures, a full growth of the problem formation starting in the second half of the XX century already. In Siberia a lot has been done to research the musical culture

(C) Siberian Federal University. All rights reserved

* Corresponding author E-mail address: preisman@list.ru 
of Novosibirsk, Tomsk, Irkutsk, Krasnoyarsk and other regional centres. Monographs, collections of works, a large number of articles in scientific journals have been published. The scope of this articles cannot embrace even a small part of them, yet it will indicate the most significant ones: "Muzykal'naia kul'tura Sibiri” (“Musical Culture of Siberia"), a fundamental three-volume monograph (six books) edited by B.A. Shindin (Muzykal'naia..., 1997), "Muzykal'naia kul'tura rossiiskikh gorodov Vostochnoi Sibiri” ("Musical Culture of the Russian Cities in Eastern Siberia"), an impressive monograph by I.V. Belonosova with rich reference materials (Belonosova, 2015), “Muzykal'naia zhizn' Krasnoiarska" ("The Musical Life of Krasnoyarsk"), the first comprehensive research of the musical culture of Krasnoyarsk by B.G. Krivosheia, L.G. Lavrusheva, E.M. Preisman (Krivosheia, Lavrusheva, Preisman, 1983), monographic studies on individual components of the development of music art in Krasnoyarsk by V.A. Averin, E.A. Vaniukova, I.V. Efimova, E.V. Prygun, et al.

The above mentioned and other works have opened new frontiers of research, the closest of them being the following ones:

- the study of musical life of the regions which has not been in the focus of musicologists' attention until recently;

- the study of the "detonators" of musical life in these regions, i.e. the activities of certain art institutions, creative teams, creative individuals.

\section{Conceptual Basis of the Research}

Russian musicological literature lacks the works with the stated conception of the regions' artistic life research. However, the very first individual steps in this direction were taken by B.V. Asafiev. In his autobiographical materials he, who travelled much, gives a brief description of his trips in many cities of Europe and Russia in 1909-1930. Among Russian cities he mentions both the names of major administrative and industrial centres (Kiev, Nizhniy Novgorod, Astrakhan, etc.) and the cities in the remote but widely known places (Kizhi, Rybinsk, Sergiev Posad, Sol'vychegodsk, etc.) (Marterialy k biografii B. Asafieva, 1982: 58-60). We argue that a prominent musicologist and composer could not fail to draw his attention to the distinctive folklore, musical life of these places. In 1921 in the memo to the Board of the Russian Institute of Art History "On the establishment of science organizations at the music faculty" he notes the need for "the research of a general state of Russian musical life till the XIX century" (Marterialy k biografii B. Asafieva, 1982: 193). In 1927 in the courses of history of music the scholar states the problem of "town and village in music: exchange and interaction" (Marterialy k biografii B. Asafieva, 1982: 239). In a year Asafiev develops "The draft of the charter of the musical regional group" of the Leningrad State Conservatory. A separate clause in it states the following requirement: "Establishment of the relations with the local provincial institutions and individuals related to some branch of musical work, and carrying out special registration of the contemporary musical life of the Union (only the USSR can be meant here - E.P., M.R.) and musical-ethnographic activities of local research and local history societies through them" (Marterialy k biografii B. Asafieva, 1982: 227). He further includes the clause "Cultural-Educational work with the aim of musical and regional history knowledge promotion" (Marterialy k biografii B. Asafieva, 1982: 227). Asafiev writes about the organization of special "libraries of musical ethnography" (Marterialy k biografii B. Asafieva, 1982: 228), publication of works in this field of scientific research and promotion of "music-and-regional history knowledge" in the format of the lectures (Marterialy k biografii B. Asafieva, 1982: 228). 
The same year the scholar hands in a memo to the Board of the Leningrad State Conservatory "On the organization of musical-historical museum" which could keep the funds of various materials about music (musical-ethnographic materials, instruments, audio-gramophone archive, manuscripts from different times, memorial materials related "to individual eras, institutions and people"), reflecting the musical life of the past and present of the Soviet Union" (Marterialy k biografii B. Asafieva, 1982: 229).

Written by Asafiev, the documents indicate that the scholar foresaw this phenomenon in outlining the direction of his study. Yet, they do not state the conception of the musical life development in the regions.

\section{Problem Statement}

One of such regions is Khakassia, an artistic face of which is largely determined by music development.

Khakassia is an industrial region. It is a region of extraction of iron, molybdenum, gold, coal, and such non-metallic mineral resources as barite, bentonite. Production of building materials is developed here. The basis of the regional economy is technologically connected hydroelectric power industry and aluminum production. The energy system of Khakassia includes the Sayano-Shushenskaya and Mainskaya hydroelectric power station. Sayanogorsk and Khakass aluminum smelters and JSC "Sayan Foil", "Tushino Factory of Nonferrous Metals Processing Ltd." (copper mill products) are located on the territory of the republic. Coal mining is carried out by two mines: the Yenisei and Khakass ones.

There is the Khakass State University named after N.F. Katanov in the republic, the university having agricultural, educational, medical and music colleges. There is the Khakass Technical Institute, a branch of the Siberian Federal
University, the Khakass Business Institute, the Abakan branch of the Modern Humanitarian Academy, a number of colleges.

The Khakass Research Institute of History, Language and Literature plays a significant role in the humanitarian sphere of the region. There is also the National Library named after N.G. Domozhakov with its great traditions and the National Museum of Local Lore named after L.R. Kyzlasov.

The republic has a wide network of media: the republican newspapers "Khabar" (in the Khakass language) and "Khakassia", weekly newspapers "Pravda Khakassii" ("The Truth of Khakassia", the newspaper of the Khakass regional branch of the Communist party) and "Piatnitsa" ("Friday"), the "Khakassia" news agency, the "Novyi Fokus" ("New Focus") Internet journal, the republican state television and radio company "Khakassia", the television network (RTS), the media group "South Siberia", the "Stroika Khakasii" ("The Construction in Khakassia") magazine, the "Khakassia-Inform" news agency, etc.

The range of art institutions is represented by the Russian Republican Drama Theatre named after Mikhail Lermontov, the "Chitigen" Khakass Drama Theatre, the "Skazka" Puppet Theatre. The musicians of the Khakass Republican Philharmonic named after V.G. Chaptykov give their concerts here. There is the Abakan Art Gallery in Khakassia. The Centre of Culture of Folk Art named after S.P. Kadyshev is very popular in the republic.

One can reasonably state a high prestige of the symphony orchestra of the Khakass Republican Philharmonic in Siberia, partly in Russia and abroad. Its eighteen-year-old activity has marked a new stage in the region's musical culture development.

In the light of Asafiev's ideas about the need to study the culture of the province and in line with the accumulated experience of the research 
of the culture of Siberia, a region constituting a significant territorial and industrial part of the country, the problem of identifying the causes of formation and study of the activity of the Khakass symphony orchestra, which has become a noticeable phenomenon, seem obvious.

However, the material for the research of the orchestra activities is limited. There are no scientific papers about it. As for the publicistic materials, there are a few newspaper articles in the local press. There are brochures, posters, the orchestra veterans' recollections that have not faded yet, some listeners' reviews.

The scarcity of the material has influenced the choice of research methods: analysis of creative documents (brochures, posters), newspaper publications, several decisions of Khakass administration concerning the orchestra, interviews with the veterans and the audience, watching the orchestra as a developing phenomenon, comparison of its activity results in different periods, elimination of consequences from the comparison of the artistic culture development in the republic in general and the orchestra development.

Application of the aforementioned methods of research made it possible to see a panorama of the orchestra formation and development, present its perspectives.

\section{Musical Culture of Khakassia of the XX century. Background of the Philharmonic Symphony Orchestra Establishment}

Establishment of the Khakass symphony orchestra is a logical consequence of the musical art development in the republic in the $\mathrm{XX}$ century. It was already in the 20 -s when there outlined a consistent, but not rapid growth in the number of cultural and educational institutions and a tendency to involve the population in folk art groups, domestic music-playing. It is known, for example, that in 1921 the cultural-educational circle of the Abakan Factory formed an orchestra (we failed to find out the information about the members). In 1922 the first people's house in Khakassia started its work in the village of Ust'Abakanskoe. In 1931 this village was renamed to the city of Abakan and in 1937 they opened the Palace of Culture there, the event turning to be significant in the spiritual life of the republic. In the 30-s - 40-s the orchestra of folk instruments under the direction of D.I. Shtygashev started its work in the Republic of Khakassia (the location is still not known).

The 40-s were marked by a visible intensification of the spiritual life of the region. In 1943 the State Pedagogical Institute was opened, the institute being the first higher educational establishment in the republic. The same year they began the construction of the largest cinema in Abakan, the cinema was later called "Pobeda" ("Victory").

The beginning of the 40 -s is the period of emergence of professional musical culture, the oldest representative of which is A.A. Kenel, a composer (1898-1970) and a student of M.O. Shteinberg. The latter was one of the founders of Siberian and, in particular, Khakass folklore. The author of the first Khakass opera "Chanar Khus i Akh Chibek" (1970) as well as symphony and chamber works implemented Khakass folk music in his creative work. In 1948 the regional house of folk art opened its doors to the public. In 1957 the national orchestra started working in the Palace of Culture. The instrumental composition was the following: homys, chatkhan, yykhov.

In 1942 the first children's music school was opened in Abakan. In 1997 it was named after A.A. Kenel. Initially, they taught the piano and the violin. Starting from the 50-s they began teaching cello, chatkhan and organized a student choir. S.S. Rivlin was the first director. 
At different times the school was headed by V.E. Miakhar, L.F. Alekseevskaia, P.R. Vorob'ev, A.A. Spirin.

In the 60-s there were three children's music schools in the Khakass autonomous region, which was part of the Krasnoyarsk Krai. In 1975 their number increased to eighteen, and in the early 80 -s there were twenty-three children's music schools in Khakassia.

The establishment of the Abakan music college was an event in the cultural life. It was opened in April 29, 1960 by Order No. 124 of the Krasnoyarsk Regional Department of Culture. From 1973 the college was housed in a new, specially constructed building in house No. 14, Viatkina Street. It is still located there. The college became the first educational institution in the region that trained professional musicians for cultural institutions (music teachers for children's music schools mainly), a center of musical education in Khakassia. As the Musical College of the Institute of Art it became a structural subdivision of the Khakass State University named after N.F. Katanov in 1994. The college was successfully headed by L.G. Revich, then L.A. Spivak.

The symphony orchestra in which both students and teachers participated played a significant role in the artistic-educational work of the college. The orchestra repertoire was fairly diverse; its activities were far beyond the scope of training. Thus, the orchestra members became an instrumental basis of the premiere of "Chanar Khus and Akh Chibek" (the first act was staged). They gave many concerts.

In 1992 the orchestra toured in BadenBaden (Germany). In 1993 the Freiburg choir came to Abakan on a return visit and performed in the hall of the Institute of Art. A few days later the orchestra and the choir gave a joint concert in the hall of the Moscow Conservatory named after P.I. Tchaikovsky. In 1995 the student symphony orchestra and the choir performed together again, in Germany (Freiburg). Moreover, the concerts were given in Switzerland, Italy. Thus, the orchestra performances contributed to the expansion of international cultural relations of both the Republic of Khakassia and the Krasnoyarsk Krai.

Talented musicians (V.V. Darmodekhin, S.A. Bulgakov (a conductor of the first act of "Chanar Khus and Akh Chibek"), G.G. Machin, A.P. Nukhov, A.V. Pronin) were at the head of the orchestra in different years. At present the student symphony orchestra is conducted by A.S. Tsatsa.

In 1989 the Khakass Republican Philharmonic was established on the basis of the Abakan concert bureau of the Krasnoyarsk regional philharmonic. The director of the philharmonic was L.I. Branchukov, its art director was G.N. Sarazhakov, an honored artist of Russia. The same year S.T. Kim established the ensemble of national songs and dances and was its director. Later the ensemble was given a new name of the "Ulger" ("Constellation") folk ensemble.

In the course of the last decade of the XX century the directors of the philharmonic were G.N. Sarazhakov (1991-1992), T.K. Sagalakova (1993), N.F. Pankova (1993-1999), then V.I. Beliaeva. The art directors were Iu.G. Topoev, an honored artist of the Republic of Khakassia (1991-1992), L.I. Tretiakov (1993-1995), S.T. Kim (1995-1999), V.G. Kirbizhekova (1999-2000), Iu.I. Nesterov (2000-2001). It was in 1993 when S.T. Kim established the ensemble of the Russian folk instruments "Lado". The ensemble was later directed by G.N. Lashkin. It was in the staff of the philharmonic.

\section{The Orchestra Staff Formation}

By 2000 the Khakass state philharmonic acquired the features of an extensive concert organization, serving a significant part of the 
audience. The prospects of expanding the philharmonic activities contributed to the formulation of the idea of a symphony orchestra formation in the republic, especially because the music college provided local creative teams with the specialists.

The idea was suggested by V.G. Chaptykov (1940-2011), who was a former Minister of culture of Khakassia. This talented musician was taught the piano by R.I. Sidorova and graduated from the Krasnoyarsk Art School, then from the Novosibirsk State Conservatory named after M.I. Glinka. The Chairman of the Government of the Republic of Khakassia Alexei Ivanovich Lebed', a brother of the Governor of the Krasnoyarsk Krai Alexander Lebed'), played a great role in the formation of the orchestra staff.

In December 27, 1999 A.I. Lebed' signed a decree of the Presidium of the Government of the Republic of Khakassia No. 267-p "On the establishment of the concert chamber orchestra of the Khakass Republican Philharmonic". The decree ran: "In order to develop the professional classical music art, further professional training of the performers of this genre and musical culture in the Republic of Khakassia the Presidium of the Government of the Republic of Khakassia decides: 1 . To agree with the proposal of the Ministry of Culture of the Republic of Khakassia on the establishment of the symphony orchestra of the Khakass Republican Philharmonic. To approve the list of staff for an orchestra of 40 people with a monthly salary budget of 34,800.00 (thirty-four thousand eight hundred) rubles and to introduce it additionally to the list of staff of the philharmonic. 2. The Ministry of Culture of the Republic of Khakassia (V.G. Chaptykov) should provide carrying out of organizational and personnel work on the establishment of the concert-chamber orchestra and bring the regulatory legal documents of the Khakass Republican Philharmonic into line up to 01.02.2000. 3. The Ministry of Finance and Economy of the Republic of Khakassia (V.I. Popov) should provide the funding for the orchestra within the amount of the "Culture and art" section defined by the law of the Republic of Khakassia "On the Republican budget for 2000 and performance report on the budget for 1999". 4. The Deputy Prime Minister of the Republic of Khakassia T.G. Borgoiakova to be charged with supervising the execution of the decree. The significance of this event in the cultural life of the republic is difficult to overestimate. The formation of such an orchestra team became an important step on the way of presenting the world musical culture masterpieces to the Khakass audience.

S.A. Reshetnikova (1954-2013), who became its first director, played an important role in the orchestra formation. She promoted the purchase of concert costumes, chairs and music stands. She participated in the organization of competitive auditions to the orchestra, which were held by the three talented and experienced musicians: a violinist A.A. Knoblokh, a clarinet player A.I. Glukhov and a French horn player V.N. Timoshchenko.

The college students and teachers played in the first orchestra staff. The organizational problem was that in those years the musicians could have a working load of not more than 1.5 standard labour rates. Yet, the teachers had this working load in the college already. However, S.A. Reshetnikova solved the problem by bringing it into the plane of the Russian legislation on the contract system.

In the future, the orchestra was generally staffed by the college graduates. The college students who later graduated from the higher musical educational institutions joined the orchestra. So, V.G. Inkizhekov, a conductor, studied at the Krasnoyarsk Institute of Art, E.V. Shtark, an orchestra concertmaster, started 
his training at the Ulan-Ude Academy of Culture and Arts and then transferred to the Krasnoyarsk Institute of Art.

The first symphony season opened in February 1, 2000. The concert musical pieces were "The Festive Overture" by D. Shostakovich, the Concerto for cello and orchestra in C major by I. Haydn (with Elena Samoilova as a soloist), the Concerto for piano and orchestra in D major by I. Haydn (with Alexander Nikiforov as a soloist), the Overture to M. Glinka's Opera "Ruslan and Lyudmila”, a few opera arias. V.G. Inkizhekov conducted the concert.

The newspaper "Abakan" responded to the opening night and published A.A. Knoblokh's article "Orkestr, na start!” (“The Orchestra, Go!"). It wrote that the orchestra is a complex body and its vitality depends on the republic leaders' attention to it. According to the information in the article, the Ministry of Culture of Khakassia knows about the difficulties the orchestra staff faced (Knoblokh, 2000). It was necessary to continue to solve the problems of the orchestra staff formation, its material security, and, most importantly, to solve creative problems: the choice of repertoire, organization of concerts. A good thing was that the orchestra began its work and this work received a positive evaluation among the audience.

However, the country went through hard times and this was reflected in the life of the orchestra and the philharmonic. By its tenth anniversary the Khakass symphony orchestra (this was an official name of the orchestra) was on the verge of collapse. The orchestra that no significant event of the national scale could get along without, the orchestra the concert programs and performances of which were increasingly in demand had no quality instruments, and the musicians did not have a decent salary. Not everything was smooth in the philharmonic. The lack of experience of arranging programmes, ignorance of mechanisms to study the artistic needs of the audience with their different social and age strata, inability to advertise the products often created unfortunate situations when a lot of efforts and money were spent on a good programme but the hall was empty. The problem of having the marketing service became urgent.

Acute problems strongly stimulated a radical re-construction of work of the philharmonic and the orchestra. It started in 2010. The efforts of S.A. Okol'nikova, the Minister of culture of the Republic of Khakassia, the programme of the Khakass republican philharmonic and the symphony orchestra development was introduced and implemented. Within the framework of this programme the wages were increased, individually made musical instruments and a bus were purchased. V.G. Inkizhekov, along with the functions of the orchestra artistic director, also took over an administrative work when he became the director of the orchestra. In collaboration with M.A. Shtark, a chorus master, he defined the repertoire policy. The prospects of touring concerts were outlined.

In February 1, 2015, during the anniversary concert, S.A. Okol'nikova gave the symphony orchestra a certificate for the purchase of apartments for young musicians. The musicians gained a sense of stability and confidence in the future.

\section{Instrumental Structure and Artistic Staff}

Nowadays the Khakass symphonic orchestra has a full double staff.

Such honored performers of the Republic of Khakassia as E.V. Shtark, an orchestra concertmaster, A.A. Knoblokh, a first violin, T.A. Shmeleva, a concertmaster of the second violins, E.Iu. Samoilova, a cellos concertmaster, V.N. Timoshchenko, a French horn, A.G. Shtark, V.P. Zaporozhets, trumpeters, S.I. Kunitsyn, 
a trombone player, V.M. Kotliar, a percussion player, are in the orchestra staff. V.G. Inkizhekov, the Director of the philharmonic, the chief conductor and artistic director of the orchestra, was conferred the title of "Honored Artist of the Republic of Khakassia". Having received their secondary education at the Abakan Music College, some performers graduated from musical higher education institutions. Among them there are pupils of A.A. Knoblokh, who worked at the college from 1979 to 1994, the students of T.N. Pavlenko, a teacher and methodologist, her pupils' pupils (Larisa Vainer, Tatiana Shepeleva, Elena Samoilova, Elena Mikheeva, Svetlana Skrepko, Anna Hudoiarova, Alexandra Lapina, Ekaterina Krasovskaia).

\section{Giving concerts}

The orchestra concert activity is organized in two directions. The first one is musical-andeducational. It is based on the performance of the world symphonic and opera classical music masterpieces. The repertoire includes Beethoven's Symphony No. 1 and Symphony No. 5, Schubert's "Unfinished Symphony", F. Mendelssohn's Symphony No. 1, A. Dvořák's symphony "From the New World", Alexander Borodin's Symphony No. 2, Tchaikovsky's Symphony No. 1, the fourth part of Mahler's Symphony No. 5, the third part of V. Kalinnikov's Symphony No. 1, C. Saint-Saens's Suite "Carnival of Animals", M. Mussorgsky's "Pictures at an Exhibition" orchestrated by M. Ravel, the suite from P. Tchaikovsky's ballet "The Nutcracker", overtures to G. Rossini's operas "Cinderella" and "William Tell", G. Verdi's "Force of Destiny", Glinka's "Ruslan and Lyudmila", Tchaikovsky's overture "The Year 1812" and Overture-Fantasia "Romeo and Juliet", Shostakovich's "Festive Overture", a large number of music pieces. The orchestra also played the symphonic works of the Khakass composers: Borgoiakov's suite
“Tun-Pai ram" and E. Ulygbashev's fragment from the suite "Alyp Khan". The orchestra played concertos for instruments and orchestra by A. Vivaldi, I. Bach, F.J. Haydn, V. Mozart, L. Beethoven, J. Brahms, N. Paganini, J. Sibelius, H. Wieniawski, S. Prokofiev, et al.

The orchestra performed excerpts from operas by A. Ponchielli, G. Pergolesi, R. Wagner, F. Poulenc, and other composers. It participated in the production of such musicals as V. Pleshak's "The First Star" based on Hans Christian Andersen's fairy tale and O. Studenkina's "Alice in Wonderland" based on L. Carroll's fantasy novel.

The second direction aimed at the involvement of new listeners to symphonic concerts. Therefore, the symphony orchestra began playing the music composed for different staffs, yet very popular in living environment. The repertoire included jazz compositions and compositions for instrumental pop groups. The orchestra played a lot of widely known music from the audience's favourite movies: "12 stul'ev" ("12 chairs"), "Shrek”, "Gardemariny, vpered!” (“Midshipmen, forward!”), “Mary Poppins", "Veselye rebiata" ("Funny guys"), "Moia liubov' na tret'em kurse" ("My love from the third academic year"), "Chelovek s bul'vara kaputsinov" ("A Man from Boulevard des Capucines"), "Obyknovennoe chudo" ("Ordinary miracle”), "Ne pokidai” ("Don’t leave”), "Titanic", "Stiliagi” ("Dudes"), "Ivan Vasil'evich meniaet professiiu" ("Ivan Vasil'evich changes occupation"), "Truffaldino from Bergamo", etc. Such concerts are willingly visited and this gives us hope that the interest in the repertoire will cause the interest to the musicians because this will contribute to the expansion of the audience of truly symphonic concerts.

A significant part of symphonic evenings are held at the base of the orchestra in the Hall of the Republican Philharmonic. In accordance with the standards of the international practice 
the orchestra plays a symphony, an instrumental concert, and a musical piece. Yet, the forms the orchestra contacts with the audience are various. So, in Abakan it has become a tradition to perform the already mentioned V. Pleshak's musical "Pod pervoi zvezdoi" ("Under the first star") on Christmas Eve. The competition of music performers named after A.A. Kenel' has been held in Khakassia for many years. The competition laureates have the honourable right to participate in the "Music of Children's Hearts" festival with the Khakass symphony orchestra. The orchestra also gives benefit concerts.

In 2015, the Khakass Republican Philharmonic implemented two major projects with the touring artists' participation. The first "The Stars of the Twenty-First Century" - was held with the support of the Ministry of culture of Russia. It gave an opportunity to meet the country's young musical elite. Mikhail Pochekin (Moscow), a violinist, the winner of the third Moscow competition named after N. Paganini, a member of the Moscow philharmonic project "The Stars of the Twenty-First Century", Natalia Lomeiko (UK), a violinist, the laureate of the international competitions named after N. Paganini and A. Stradivarius, Vladislav Kosarov (Moscow), a pianist and the laureate of the international competitions, a participant of the "Romance of a Romance" programme on TV channel "Kul'tura" ("Culture"), were invited to the project. The second project - "The Gallery of Stars" - was also supported by the Ministry of culture of the Russian Federation. It introduced well-known performers to the audience. Thus, within the framework of the project Ramiro Arista, an Argentinean conductor who visited Khakassia with the "Viva Latina!" programme and delighted the audience last year, performed with the symphony orchestra.

Every year the philharmonic holds a series of concerts for children and adults
"Musical fantasies", the concerts being a kind of performances during which animated films accompanied by live sound of the symphony orchestra are shown on a big screen.

As is customary, symphony concerts have become a creative tribune for many touring performers. A famous jazz pianist Daniel Kramer was one of the first (2010). Many people did not believe in his arrival even when the posters appeared. There were rumors that the day before he gave a regional orchestra a scolding right from the stage. But in fact Daniel Kramer was not only a serious musician but a wise colleague, who did justice to the orchestra's efforts. Undoubtedly, he was well aware that the fate of the orchestra largely depends on the evaluation he gives to the orchestra in his conversation with the officials. Kramer then said, referring to both the orchestra creators and the musicians: "You are incredibly lucky as you have managed to keep a good working orchestra here". He said it sincerely. The pianist Alexander Vershinin, Ekaterina Mechetina; the violinists Maxim Fedotov, Marina Kuzina, Alexei Koshvanets; the cellists Denis Shapovalov and Oleg Sendetsky gave concerts with the orchestra. Such stars of the world opera stage as Dmitri Khvorostovsky, Tatiana Pavlovskaya, Irina Makarova, Ekaterina Lekhina, Jose Carreras (Spain) also sang with the orchestra.

Viacheslav Inkizhekov often gives his conductor's place to his famous colleagues, rightly considering that the orchestra must be able to work with different creative directors, and the audience must be able to understand the conductor's art. So, Winston Vogel (USA) worked with the Khakass symphonic orchestra. He showed a programme of American music. Anatoly Rybalko (Saint Petersburg) staged "Alice in Wonderland". Igor Novikov conducted the "Small Opera Masterpieces" project, in which they played G. Pergolesi's opera "The 
Maid Mistress" and a fragment of F. Poulenc's mono-opera "The Human Voice". In one of the seasons the principal guest conductor was Denis Shapovalov, a cellist and a conductor, M. Rostropovich's pupil.

The orchestra tours a lot. Its concerts are often held in Khakassia and the south of the Krasnoyarsk Krai: Minusinsk, Chernogorsk, Ust'-Abakan, Sayanogorsk, Abaza, Askiz. On the anniversary of the tragedy at the SayanoShushenskaya hydroelectric power station (August 16, 2010) the orchestra performed in the village of Cheremushki. It performed on an open area before the Palace of Culture "Energetik". J.S. Bach's Concerto for two violins and orchestra was performed by the violinists A. Subrakova and L. Telkova, the laureates of the international competitions who later graduated from the St. Petersburg Conservatory. The orchestra also gave concerts in Tomsk. In 2007 they gave a concert in the Mossovet Drama Theatre within the framework of the events dedicated to the 300-th anniversary of accession of Khakassia to Russia.

Four years later, the Khakass symphonic orchestra was invited to Cannes (France), hosting the fourteenth festival of the Russian art. The programme comprised the symphonic music of West European and Russian composers as well as music works by the Khakass authors and aroused great interest among the European audience. One of the concerts was broadcast on Channel 1 of the Russian television.

\section{Conclusion}

Having reviewed the activities of the Khakass symphony orchestra, it should be stated that the orchestra was established to meet the audience's artistic needs, which increased in connection with strengthening of the republic's economy and, therefore, the increase in the population's material standard of living. The orchestra became one of the most significant phenomena in the artistic culture of the southern region of the Krasnoyarsk Krai, its organic element. The orchestra staff has been improving their skills, expanding the repertoire, intensively searching for various forms of giving concerts. The orchestra has firmly announced itself on the national and international levels.

Today, the orchestra appears to be

- an intensification factor of the artistic and, in particular, musical life of Abakan;

- a means of musical education of the population of the republic and the south of the Krasnoyarsk Krai;

- a creative laboratory where the Khakass composers' works are tested and given a "start in life".

The orchestra activity is supported by the authorities of the republic. The region's further industrial development and its economy growth are keys to the extension of the orchestra staff's creative perspectives.

\section{Acknowledgement}

The authors express their deep gratitude to V.G. Inkizhekov, the artistic director and chief conductor of the Khakass symphony orchestra, A.A. Knoblokh, E.Iu. Samoilova, E.B. Shtark, the orchestra performers, A.V. Golysh, O.A. Ivandaeva, N.A. Karapetian, A.V. Maliutin, E.V. Tsygankova, the listeners, for the provided information on the orchestra activities, which was made use of in this article.

\section{References}

Belonosova, I.V. (2015). Muzykal'naia kul'tura rossiiskikh gorodov Vostochnoi Sibiri [Musical Culture of the Russian Cities in Eastern Siberia]. Krasnoyarsk, Krasnoyarsk State Institute of Art, $380 \mathrm{p}$. 
Knoblokh, A. (2000). Orkestr, na start! [The Orchestra, Go!]. Abakan, The Daily Newspaper, 10, 29 January.

Krivosheia, B.G., Lavrusheva, L.G., Preisman, E.M. (1983). Muzykal'naia zhizn' Krasnoiarska [The Musical Life of Krasnoyarsk]. Krasnoyarsk, Book Publishing House, 176 p.

Marterialy k biografii B. Asafieva [Materials for B. Asafiev's Biography] (1982). Ed. by A. Kriukov. Leningrad, Muzyka, 264 p.

Morozova, N. (2000). Kadry reshaiut vse [Cadres are All-Important]. In The Daily Newspaper, 10, 22 January.

Muzykal'naia kul'tura Sibiri [Musical Culture of Siberia] (1997). Ed. by B.A. Shindin: in 3 vol. Novosibirsk, Novosibirsk State Conservatory (Academy) named after M.I. Glinka.

Oplakanskaia, R.N., Tuguzhekov, V.N. (2009). Abakan, Istoricheskaia entsiklopediia Sibiri [Abakan, Historical Encyclopedia of Siberia], (1), 6-7.

\title{
Симфонический оркестр Хакасии \\ в контексте развития музыкальной культуры республики
}

\author{
Э.М. Прейсман ${ }^{a}$ М.И. Раздольева ${ }^{\sigma}$ \\ ${ }^{a}$ Красноярский государственный институт искусств \\ Россия, 660049, Красноярск, ул. Ленина, 22 \\ ${ }^{6}$ Детская музыкальная школа № 12 \\ Россия, 660130, Красноярск, ул. Словцуова, 11
}

\begin{abstract}
В статье рассматривается симфонический оркестр Хакасии как явление, обусловленное промышленным развитием республики, стимулировавщим подъем художественной культуры. Осмысливаются экономические и социальные предпосылки, организационные механизмы художественного становления коллектива. На основании анализа творческих документов (буклетов, афии, газетных публикаиий) и решений административных органов, бесед с ветеранами оркестра и некоторыми его слушателями, сравнения результатов деятельности коллектива в разные периоды выявлены пути развития оркестра, его творческий контингент, инструментальная структура, особенности репертуара и характерные черты концертирования, а также перспективы деятельности. Оркестр предстает органичным слагаемым художественной культуры Хакасии, фактором интенсификации музыкальной жизни Абакана, средством художественного просветительства населения юга Красноярского края, творческой лабораторией, апробирующей произведения хакасских композиторов. Деятельность коллектива поддержана руководителями республики, и в этом залог расширения его творческих перспектив.

Ключевые слова: Хакасия, художественная культура, музыкальная жизнь, Хакасская республиканская филармония им. В.Г. Чаптыкова, Абаканское музыкальное училище, симфонический оркестр, В.Г. Инкижеков, симфония, инструментальный кониерт, музыка кино, международные культурные связи.
\end{abstract}

Научная спеииальность: 17.00.09- теория и история искусства. 